\title{
Liliopsida, Arecaceae, Geonoma undata Klotzsch: Range extension for Zulia state, Venezuela
}

\author{
Juan Carlos Arias ${ }^{1 *}$ and Fred Stauffer ${ }^{2}$ \\ 1 Universidad del Zulia, Departamento de Biología, Facultad Experimental de Ciencias. Apartado postal 526. Maracaibo 4011, Venezuela \\ 2 Conservatoire et Jardin botaniques de la Ville de Genève. Ch. de l'Impératrice 1, CP 60, CH-1292. Chambésy, Genève, Switzerland \\ * Corresponding author. E-mail: jcariasj@gmail.com
}

\begin{abstract}
The occurrence of the palm Geonoma undata Klotzsch is registered for the first time for the state of Zulia, Venezuela, as result of a floristic survey made at Cerro Las Antenas, in the Serranía de Perijá. This species is catalogued as "vulnerable" according to the Red Book of Venezuelan Flora.
\end{abstract}

Geonoma is one of the most diverse Neotropical palm genera and one of the most important numerically in the Andean region (Borchsenius and Moraes 2006; Mondragon et al. 2008). The genus consists of 68 species (Henderson 2011; The Plant List 2012) and is distributed from Mexico to Paraguay. In Venezuela there are 19 species (Stauffer 1999) distributed in the temperate rain forest of the Cordillera de la Costa and the Venezuelan Andes (Hoyos and Braun 2001). Geonoma undata Klotzsch has been known from South and Central America (Henderson et al. 1995; Govaerts and Dransfield 2005). Stauffer (1999) reported this species for the states of Aragua, Barinas, Federal District, Falcon, Táchira, Trujillo and Portuguesa. More recently Mondragon et al. (2008) reported it for Lara state. Here we extend the distribution of $G$. undata to northwestern Venezuela (Figure 1).

The exemplar was collected at $10^{\circ} 20^{\prime} 41^{\prime \prime} \mathrm{N}$ and $072^{\circ} 33^{\prime} 39^{\prime \prime} \mathrm{W}$, at $1456 \mathrm{~m}$ on the northeast slope of Cerro Las Antenas in the Serranía de Perijá, near Caño De Oro, a tributary of the Lajas river in the Municipio Rosario de Perijá, Zulia state, northwestern Venezuela.

Botanical Description: Medium sized palm, about 6 $\mathrm{m}$ tall, solitary; erect trunk of about $10 \mathrm{~cm}$, light brown. The crown shaft consists of 8 pinnate leaves, of from 1.4 to $2.5 \mathrm{~m}$ long, leaf sheath well developed, red; leaves with 10-12 pairs of pinnae, irregular or almost regularly divided, wide or narrow, open in the same plane or rarely some in different planes and the apex pendulous, giving the leaf a plumose appearance. Inflorescence paniculate, arising below the leaves, branching into 2 or 3 orders, peduncle 15 to $32 \mathrm{~cm}$, rachis 54 to $69 \mathrm{~cm}, 11$ to 24 primary branches; floral axes from 12 to $47 \mathrm{~cm}$ long, reddish in fruit. Small unisexual flowers, in groups of 3 with a female in the center and two male to the sides. Fruit a drupe ovoid apiculate at apex, 8 to $9 \mathrm{~mm}$ long by 6 to $7 \mathrm{~mm}$ wide, black when ripe (Figure 2).

Type: VENEZUELA. Miranda: Tovar, no date, H. Karsten 26 (holotype not known; isotype BM!).

Cited Botanical Specimens:

DISTRITIO CAPITAL: Agua Negra; 08-III-1940; Tamayo 1239 (VEN); Cerro El Ávila, 1.850-2.000 msnm; 03-VII1966; Braun s.n. (VEN 113468); Cerro Ávila, los Caimitos, faldas pendiente afluentes de las cabeceras de la quebrada Guayabal, a lo largo de la senda entre Fila de Ávila y Los Venados, 1.900 msnm, 11-XII-1976; Steyermark y Huber 111777 (VEN); Cerro El Ávila, quebrada Chacaíto, 1.6001.650 msnm; 21-II-1977; Manara s.n. (VEN 113313); Along road to Pueblo Maya, 0,5 km w of its junction with La Victoria-Colonia Tovar higway, 2.070-2.200 msl, 10²4' $\mathrm{N}, 67^{\circ} 20^{\prime}$ W; Luteyn, Mori, Holmgren y Steyermark 8321 (VEN); Departamento Libertador, a lo largo del camino Costa de Maya, no de la Colonia Tovar, 3-5 km desde la carretera principal de La Victoria-Colonia Tovar, 2.1002.240 msnm, $10^{\circ} 25^{\prime}$ N, 67²0' 0; 19-XII-1982; Steyermak, Davidse y Liesner 127836 (VEN); 1.500-2.100 msnm, V-1983; Gentry, Rodríguez y Sinchi 41266 (M0); 2.1002.200 msnm, $10^{\circ} 26^{\prime} \mathrm{N}, 67^{\circ} 21^{\prime}$ 0; VI-1984; Davidse y Miller 28010 (MO); Cordillera de La Costa, Cerro El Ávila, pico El Ávila, lado s, 2.100 msnm, 10³2,6’ N, 6652,5’ 0; 19-VIII1991; Meier 306-307 (VEN); Cordillera de La Costa, Cerro El Ávila, pico El Ávila, lado s, abajo del Hotel Humbolt, 2.050 msnm, 10³2,6’ N, 6652,5’ 0; 26-VIII-1991; Meier 377 (VEN); Monumento Natural Pico Codazzi, Cordillera de La Costa, carretera Arco de La Colonia Tovar-Puerto Cruz, 1 km desde el Arco, 2.200-2.280 msnm, 10²6’00" N, 6714'30" 0; 07-II-2000; Meier, Mostacero y Borjas 64666477 (VEN).

FALCÓN: Sierra de San Luís, vecindad del Hotel Parador, al s de la Tabla, 1.450 msnm, 16-VII-1967; Steyermark 98971 (VEN); Sierra de San Luís, sector El Chorro, 1430 m.s.n.m; R. Liesner, González y Wingfield 8224 (CORO); Sierra de San Luís, Sector El Chorro, 1380 m.s.n.m, 12-VII2009; J.C. Arias 096 (HMBLUZ).

MIRANDA: Dtto. Urdaneta, Cordillera del Interior, Macizo del Golfo Triste, al so de Ocumare del Tuy, 1.000 msnm, 1003'30" N, 6653'30" 0; 22-VIII-2001; Meier y Nehlin 8582 (VEN).

LARA. Municipio Morán, quebrada que cruza la carretera en sector Villanuevita, 1.510 msnm, 5-VII-2002; Alvarado, Acosta, Álvarez, Valera, León y Lozada 1464 (UCOB); municipio Morán, quebrada Burón, naciente Ojo de Agua, 1.617 msnm, 09³4'51" N, 6950’46,7” 0; 6-V2004; Alvarado, Mondragón y Valera 2357 (UCOB).

PORTUGUESA: $50 \mathrm{~km}$ nw of Guanare, 15 to $17 \mathrm{~km}$ 
n of Chabasquén, 1, 300-1,500 msl, 09²8' N, 695 $55^{\prime}$ W; 15-III-1982; Liesner, González, Stergios y Aymard 12738 (VEN); $15 \mathrm{~km}$ al e de Chabasquén, $67 \mathrm{~km}$ al no de Guanare, 1.450-1.520 msnm, 09 $26^{\prime}-27^{\prime} \mathrm{N}, 6^{\circ} 54^{\prime}-55^{\prime} \mathrm{O}$; Steyermark, Liesner y Stergios 126615-126691 (VEN, PORT); municipio Guanare, cresta de La Fila de San José de

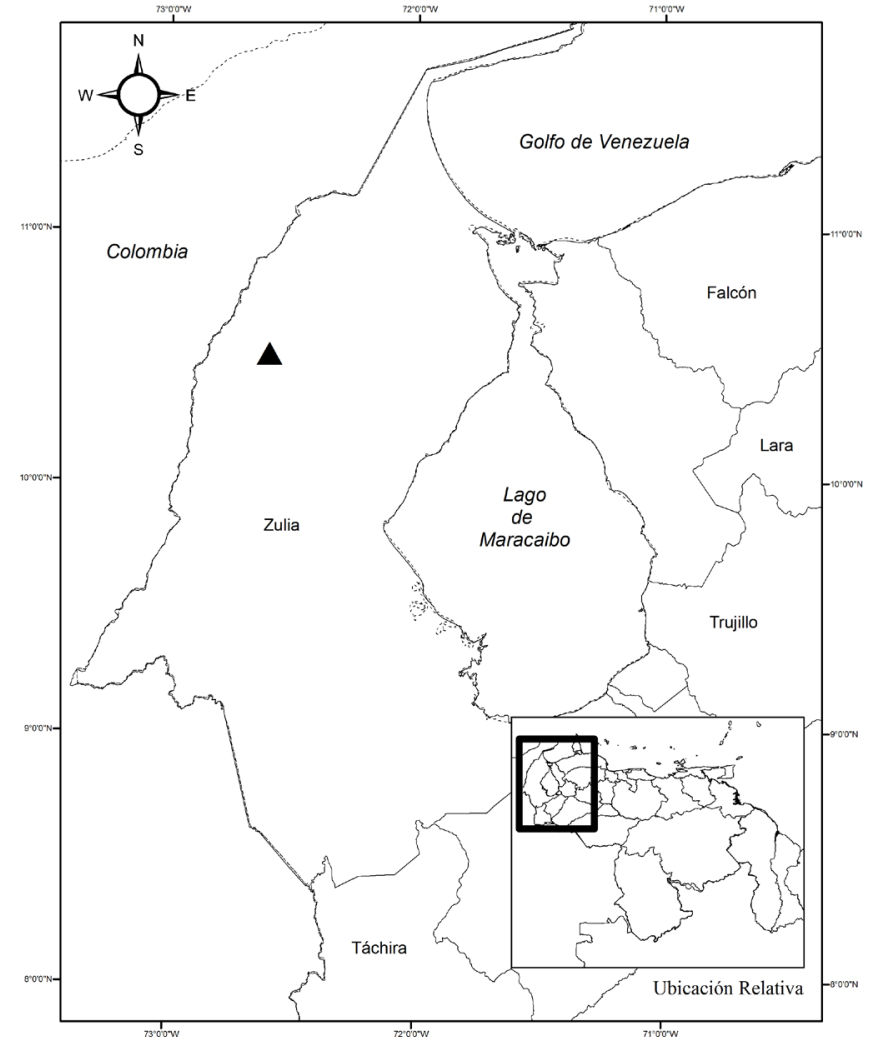

FIGURE 1. Location of record. la Montaña, $1.700 \mathrm{msnm}, 09^{\circ} 25^{\prime} \mathrm{N}, 6^{\circ} 46^{\prime}$ 0; 19-VI-2001; Dorr y Stergios 9044 (VEN, PORT); dtto. Sucre, Parque Nacional Guaramacal, sector Paramito-La Aguadita, 1.800 msnm, 09¹9,3’ N, 704,25’ 0; 13-V-1999; Henriquez y Yustiz 1613-1627 (PORT); municipio Sucre, Parque Nacional Guaramacal, sector La Divisoria de La Concepción, 1.560 msnm, UTM 19380077E, 10270005N; 20-VII-1999; Cuello y Cuello 1731 (PORT); municipio Sucre, parroquia San Rafael de Palo Alzao, 1.550 msnm, UTM 1903812E, 1031297N; 25-I-2004; Henriquez 38 (PORT).

TRUJILLO: Entre Boconó y El Batatal, 1.800 msnm, 05IX-1966; Steyermark y Rabe 97389 (VEN); dtto. Boconó, Parque Nacional Guaramacal, 1.800 msnm, 09¹0' N, 70¹8' 0; 28-X-1998; Dorr, Briceño, Briceño y Caracas 8536 (VEN); municipio Boconó, Parque Nacional Guaramacal, bosque montano cerca Quebrada Honda, 1.900-2.000 msnm, UTM 19359029E, 1011815N; 28-XII-2000; Dorr y Stergios 8747 (VEN, PORT); municipio Boconó, Parque Nacional Guaramacal, $1.350 \mathrm{msnm}$, UTM 378834E, 1025276N; 18/20-XI-2002; Cuello, León, Bastidas y Tovar 2509 (PORT).

YARACUY: Dtto. Nirgua, Cerro Azul (Tucuragua) cerca de límite del estado Cojedes, 1.600-1.690 msnm, 0959’ N, 68³7' 0; 24-I-1999; Meier y Kunert 4605 (VEN).

ZULIA: Serranía de Perijá, Cerro Las Antenas, 1456 m.s.n.m, between $10^{\circ} 20^{\prime} 41^{\prime \prime} \mathrm{N}$ and $072^{\circ} 33^{\prime} 39^{\prime \prime} \mathrm{W}$; 25 -VI2009; J.C. Arias 385 (HMBLUZ).

Brief note on status of $G$. undata in Zulia state, Venezuela. As a result of the floristic survey carried out in June 2009. Only one individual of $G$. undata was found near an intersection of roads leading to two sections of the upper basin of the Lajas river. This single individual

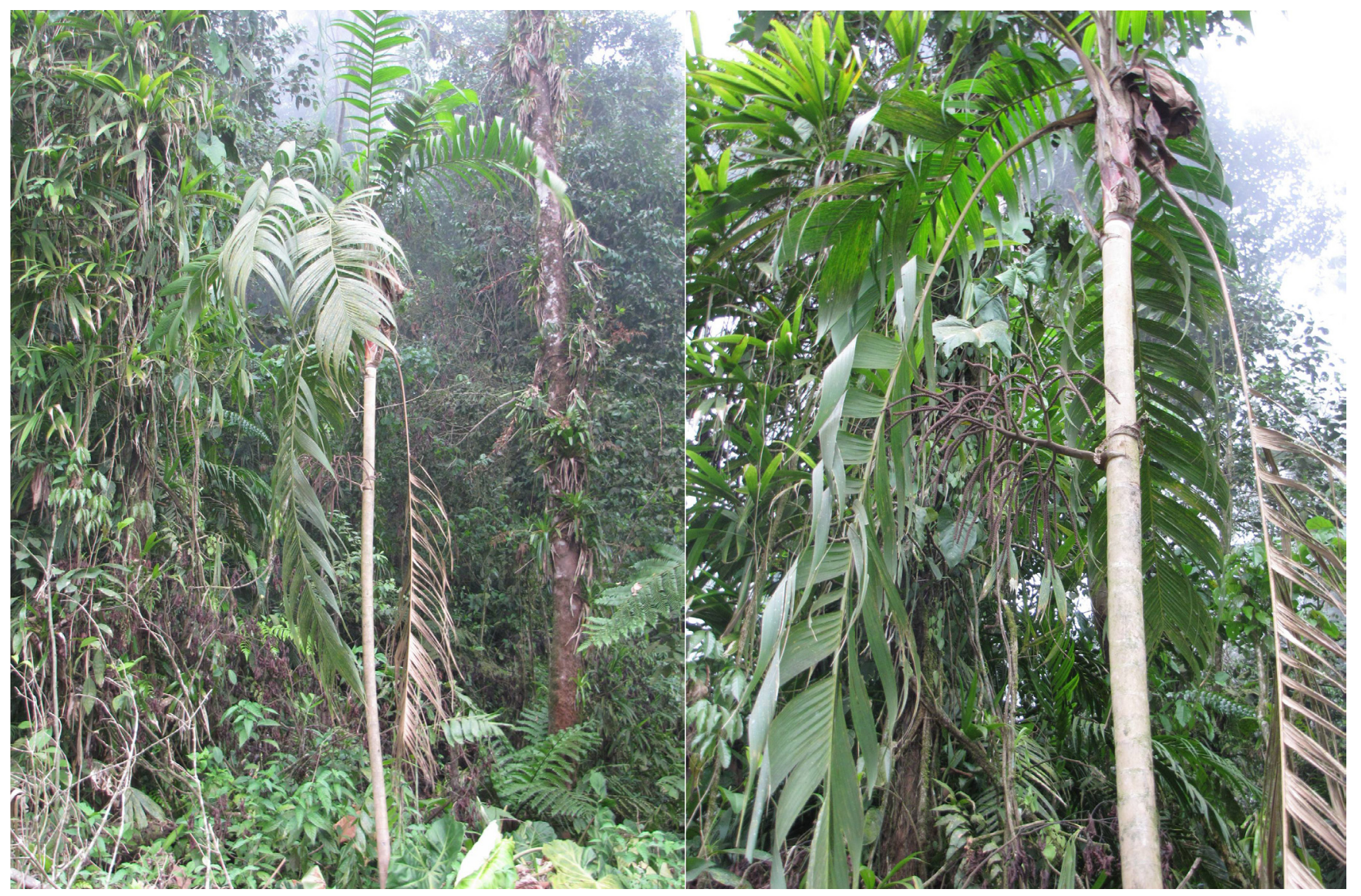

FigurE 2. Individual (left) and inflorescence and leaf sheath (right) of Geonoma undata Klotzsch. 
is at risk of disappearing being very exposed at the side of the road. Some authors (Stauffer 1999, Mondragón et al. 2008, Maciel and Mendoza 2011) noted that the natural habitat of species such as $G$. interrupta var. interrupta, $G$. spinescens and $G$. undata from the cloud forests of the states of Aragua, Distrito Federal, Lara, Miranda and Yaracuy has been heavily altered by farming and urban development. In addition, the natural habitat of $G$. undata in the upper basin of the Lajas River in Zulia state is highly threatened by the increasing land use, mainly for the cultivation of Xanthosoma sagittifolium (L.) Schott, a tuber commonly known as malanga. It is urgent to study systematically the flora of this region which is disappearing quickly and still is poorly known, since it is difficult to carry out successful plans of conservation and ecological restoration.

In Venezuela, G. undata is listed as vulnerable (Llamozas et al. 2003), but it is necessary to carry out research on their current population biology to know its real status and establish the appropriate policies for conservation.

ACKNOWLeDgments: The first author wants to thanks to Fundación Provita and the Iniciativa de Especies Amenazadas-IEA (Endangered Species Initiative) for their support for the development of a research project for the conservation of this endangered species. We thank to Carlos Portillo (IVIC - Zulia) for kindly providing the location map.

\section{Literature Cited}

Borchsenius, F. and M. Moraes. 2006. Diversidad y usos de palmeras andinas (Arecaceae); p. 412-433 In M. Moraes R., B. Øllgaard, L. P. Kvist, F. Borchsenius and H. Balslev (ed.). Botánica Económica de los Andes Centrales. La Paz: Universidad Mayor de San Andrés.

Govaerts, R. and Dransfield, J. 2005. World Checklist of Palms. Kew: Royal Botanic Gardens. 223 p.

Henderson, A., G. Galeano, and R. Bernal. 1995. Field guide to the Palms of the Americas. Princeton: Princeton University Press. 353 p.

Henderson, A. 2011. A revision of Geonoma (Arecaceae). Phytotaxa 17:1271.

Hokche, O. P.E. Berry and O. Huber. 2008. Nuevo Catalogo de la Flora Vascular de Venezuela. Caracas: Fundación Instituto Botánico de Venezuela "Dr. Tobias Lasser". 859 p.

Hoyos, J. and A. Braun. 2001. Palmas en Venezuela: autóctonas y exóticas. Caracas: Sociedad de Ciencias Naturales La Salle. 424 p.

LLamozas, S., R. Duno, W. Meier, R. Riina, F. Stauffer, G. Aymard, O. Huber and R. Ortiz. 2003. Libro Rojo de la flora venezolana. Caracas: Provita, Fundación Polar y Fundación Instituto Botánico de Venezuela. Dr. Tobias Lasser. 558 p.

Maciel, N. and A. Mendoza. 2011. Palmeras de la Región Centro Occidental de Venezuela: diversidad y amenazas con relación al potencial ornamental. Revista de la Facultad de Agronomía (LUZ) 28(Supl. 1): 200-212.

Mondragón, A., L. Álvarez, H. Alvarado and M. Dávila. 2008. Primer reporte de Geonoma undata klotzsch (Arecaceae) en el Estado Lara, Venezuela. Boletín del centro de investigaciones biológicas 42(2): 275280.

Stauffer, F. 1999. Datos preliminares para la actualización de la flora de palmas (Arecaceae) de Venezuela. Acta Botanica Venezuelana 22: 77107.

The Plant List. 2012. The plant list. Electronic database accessible at http://www.theplantlist.org. Captured in April 2012.

RECEIVED: July 2012

ACCEPTED: January 2013

PUBLISHED ONLINE: May 2013

EDITORIAL RESPONSIBILITY: Frederico Augusto G. Guilherme 